\title{
RUMINAL DEGRADABILITY OF DRY MATTER AND CRUDE PROTEIN FROM MOIST DEHULLED LUPIN AND EXTRUDED RAPESEED MEAL
}

\author{
Claudia Barchiesi-Ferrari ${ }^{1,2 *}$, and René Anrique ${ }^{2}$
}

The flow of ruminal undegradable protein (RUP) to the small intestine can be increased if ruminal degradation of dietary protein is reduced. The objective of this study was to evaluate the effect of extrusion on ruminal degradability of dry matter (DM) and crude protein (CP) from dehulled lupin (Lupinus albus L.) (DL) and rapeseed (Brassica napus L.) meal (RM). Unextruded soybean (Glicine max L.) meal (SBM) was used as a control. The DL was extruded at $130{ }^{\circ} \mathrm{C}$ with $20 \%$ moisture and RM was extruded at $120{ }^{\circ} \mathrm{C}$ with $20 \%$ moisture. Ruminal degradability was evaluated in situ by incubating feed samples for $2,4,8,12,24$, and $48 \mathrm{~h}$ of fermentation in the rumen using three rumen-fistulated dairy cows. Values of CP soluble fraction (" $a$ ") in SBM, DL, extruded dehulled lupin (EDL), RM, and extruded rapeseed meal (ERM) was lower in the extruded feeds $(\mathrm{P}<0.05)$. The slowly degradable fraction (" $b$ ") of SBM, DL, EDL, RM, and ERM was 858, 593, 622, 451 , and $457 \mathrm{~g} \mathrm{~kg}^{-1}$, respectively, and was increased by extrusion $(\mathrm{P}<0.05)$. Extrusion reduced the effective degradability (ED) of CP in lupin from 807 to $788 \mathrm{~g} \mathrm{~kg}^{-1} ; \mathrm{k}_{\mathrm{p}}=0.05 \mathrm{~h}^{-1}$ while ED was reduced from 868 to $789 \mathrm{~g} \mathrm{~kg}^{-1} ; \mathrm{k}_{\mathrm{p}}=0.05 \mathrm{~h}^{-1}$ in ERM. This resulted in an increase in RUP of 8.95\% in EDL $(\mathrm{P}<0.05)$; the increase was $37.35 \%(\mathrm{P}<0.05)$ in ERM. It may be concluded that extrusion in the presence of moisture reduced the degradability of CP, particularly in the case of ERM.

Key words: Extrusion, protein supplements, protein degradation, soybean meal, cattle.

$\mathrm{I}_{\mathrm{i}}^{\mathrm{n}}$ $\mathrm{n}$ ruminants, the availability of amino acids (AA) in the intestine will depend on the quantity of metabolizable protein (MP), which is made up of microbial protein escaping from the rumen, dietary protein not degraded in the rumen, and endogenous protein (NRC, 2001). Microbial protein generally constitutes most of the amino acids digested in the small intestine of ruminants and has a high biological value (Schwab et al., 2005). However, even at optimized rumen fermentation, microbial protein production could be a limiting factor to meet MP requirements for the high-producing dairy cow. Dietary proteins that escape degradation in the rumen are thus a significant factor in determining the protein value of feeds (Aufrère et al., 2001). The flow of ruminal undegradable protein (RUP) and total protein to the small intestine can be increased if ruminal degradation of dietary protein is reduced (Mogensen et al., 2008). This requires feeds that provide more RUP and increase AA availability in the intestine.

Protein-rich feeds of plant origin, such as lupin (Lupinus albus L.), soybean (Glicine max L.) meal, and rapeseed (Brassica napus L.) meal typically have high

${ }^{1}$ Universidad de La Frontera, Facultad de Ciencias Agropecuarias y Forestales, Av. Francisco Salazar 01145, Temuco, Chile. *Corresponding author (cbarchi@ufro.cl).

${ }^{2}$ Universidad Austral de Chile, Facultad de Ciencias Agrarias, Casilla 567, Valdivia, Chile.

Received: 20 December 2010.

Accepted: 28 April 2011. ruminal degradability (Vanhatalo et al., 1995; Tuncer and Sacakli, 2003; Wright et al, 2005). Thus, the advantages of using good quality protein, in terms of the balance between essential AA and digestibility, are lost due to extensive protein degradation in the rumen to peptides, amino acids, and ammonium (Tuncer and Sacakli, 2003).

One alternative to increase MP input is using protein-rich feeds that are artificially protected from ruminal degradation, which means more available nondegradable protein. Various physical and chemical treatments have been used to pursue this objective. One of these is controlled heat application, which allows protein degradation in the rumen to be reduced through denaturalization processes and Maillard reactions, thus reducing solubility and protein degradation rate in the rumen (Moshtaghi Nia and Ingalls, 1995). Applying both heat and humidity can increase processing efficiency and favor the Maillard reaction (Guada, 1993, Hoskin and Dimick, 1995). Extrusion is an attractive method because it promotes starch gelatinization (Svihus et al., 2005) and generates partial protein denaturalization, which can reduce ruminal degradability of $\mathrm{CP}$-rich feeds. It has been found that applying this method to oil seeds, such as rapeseed and its by-products, increases the supply of available AA for digestion in the small intestine (Sarrazin et al., 2003). The objective of this study was to evaluate the effect of moist extrusion on ruminal degradability of dry matter and crude protein from dehulled lupin and rapeseed meal. 


\section{MATERIALS AND METHODS}

\section{Animals and feeds}

Three Friesian rumen-fistulated dairy cows were used to assess the effect of extrusion on ruminal degradation. The cows were kept in a pasture dominated by Lolium perenne, Bromus valdivianus, and Holcus lanatus and received 4 $\mathrm{kg} \mathrm{d}^{-1}$ of a commercial concentrate $\left(160 \mathrm{~g} \mathrm{~kg}^{-1} \mathrm{CP}\right.$, at 06:00 and 16:30 h). Five feeds were evaluated: unextruded dehulled lupin (DL), extruded dehulled lupin (EDL), unextruded rapeseed meal (obtained by cold extraction of oil under pressure) (RM), extruded rapeseed meal (ERM), and unextruded soybean meal (SBM). Before extrusion, feeds were ground in a mill with a $3 \mathrm{~mm}$ mesh (Ciclotec, Tecator, Hoganas, Sweden). Extrusion experiments were performed with a Hake PolyDrive 0-120 Nm (Thermo Electron, Karlsruhe GmbH, Germany) laboratory singlescrew extruder with 25:1 barrel length and diameter ratio, a 19-mm internal barrel diameter, 3:1 screw compression ratio, and a $3-\mathrm{mm}$ diameter die nozzle. The extruder was mechanically fed at a rate of $3.6 \mathrm{~kg}^{-1}$. Extrusion conditions were established at the die temperature of $110{ }^{\circ} \mathrm{C}$ and screw speed of $80 \mathrm{rpm}$. The barrel had three sections with independently controlled electric heaters. Compressed air was circulated around the barrel to maintain precise temperature control of the barrel and die assemblies. During this stage, in situ degradability of SBM, DL, EDL, RM, and ERM were evaluated. The EDL and ERM were extruded at $130{ }^{\circ} \mathrm{C}-20 \%$ moisture and $120{ }^{\circ} \mathrm{C}-20 \%$ moisture, respectively.

\section{In situ evaluation of ruminal degradability}

A sample of $2.5 \mathrm{~g}$ of feed was put into polyester bags $(5 \times$ $11 \mathrm{~cm}, 40$ to $60-\mathrm{mm}$ pore size) (Ankom, Turk Hill, New York, USA) to achieve a ratio of $16 \mathrm{mg} \mathrm{cm}^{-2}$. There were two incubation periods where the bags were placed in the rumen of three fistulated cows at 2, 4, 8, 12, 24, and $48 \mathrm{~h}$ incubation times. Two replicates were performed on each cow at 2, 4, and $8 \mathrm{~h}$ while the 12,24 , and $48 \mathrm{~h}$ periods were replicated three times. The bags were introduced in reverse order of the incubation period so that they could all be removed at the same time (NRC, 2001). Prior to ruminal incubation, bags were placed in porous laundry bags of approximately $20 \times 30 \mathrm{~cm}$ and soaked in tepid water $\left(30^{\circ} \mathrm{C}\right)$ for $20 \mathrm{~min}$ (Borucki-Castro et al., 2007). Once the bags were extracted from the rumen, they were washed in tap water and stored at $-20{ }^{\circ} \mathrm{C}$ for at least $24 \mathrm{~h}$. Bags were unfrozen and washed with cold water in a semi-automatic machine prior to laboratory analysis (González et al., 2006) for $10 \mathrm{~min}$ and dried at 60 ${ }^{\circ} \mathrm{C}$ for $48 \mathrm{~h}$ in a forced air oven.

To determine soluble $\mathrm{N}$, bags with feed samples were soaked in warm water $\left(40{ }^{\circ} \mathrm{C}\right)$ for $2 \mathrm{~h}$ and then dried at $60{ }^{\circ} \mathrm{C}$ for $48 \mathrm{~h}$. Soluble $\mathrm{N}$ corresponded to the difference between total initial $\mathrm{N}$ and what remained in the bags (Aufrère et al., 2001).

\section{Laboratory analysis}

Dry matter (DM) (AOAC, 1995, method 930.15) and crude protein (CP) by Micro Kjeldhal (AOAC, 1995, method 984.13) were determined in feed samples and residues after incubation. In addition, feed samples were analyzed for starch (AOAC, 1995, method 996.11 and AACC, 2000, method 76.13), ether extract (EE) (AOAC, 1995, method 920.39), total ash (TA) (AOAC, 1995, method 942.05), acid detergent fiber (ADF) (AOAC, 1995, method 973.18), neutral detergent fiber (NDF) (Van Soest et al., 1991), and digestible organic matter in DM (D value) (Goering and Van Soest, 1972). Acid detergent insoluble nitrogen (ADIN) was also analyzed in the incubation residues (Van Soest et al., 1991).

\section{Statistical analysis}

Feed composition was analyzed by ANOVA and the GLM procedure according to a completely randomized model: $Y_{i j}: \mu+T_{j}+e_{i j}$ where: $Y_{i j}$ is the response variable; $\mu$ is the mean; $T_{j}$ is the effect of the $j^{\text {th }}$ treatment; and $e_{i j}$ is the experimental error. The significance level was set at $\mathrm{P}<0.05$. When the treatment effect was significant, differences between mean values were determined with LSMEANS statements in the JMP computer program, Version 8 (SAS Institute, 2009).

Each time, the disappearance of DM and CP from the nylon bags was calculated from the respective amounts remaining after ruminal incubation. In situ degradability kinetics for DM and CP was evaluated by the exponential model (Orskov and McDonald, 1979): $p=a+b\left(1-\exp ^{-\mathrm{kd} t}\right)$. The model assumes that there is a soluble fraction " $a$ ", a potentially degradable insoluble fraction " $b$ ", and a constant " $\mathrm{k}_{\mathrm{d}}$ " that represents the degradation rate of the fraction " $b$ " per unit of time. Estimation parameters of " $a$ ", " $b$ ", and " $\mathrm{k}_{\mathrm{d}}$ " were obtained by adjusting the model by the nonlinear regression procedure NLIN. Effective degradability of DM and CP (Orskov and McDonald, 1979) was determined as $\mathrm{ED}=\left(a+b \mathrm{k}_{\mathrm{d}}\right) /\left(\mathrm{k}_{\mathrm{d}}+k_{\mathrm{p}}\right)$ with three solid passage rates in the rumen $(0.02,0.05$, and 0.08 $\mathrm{h}^{-1}$ ) representing low, medium, and high intake levels, respectively (Agricultural Research Council, 1984). Rumen undegradable CP was determined by RUP $\left(\mathrm{g} \mathrm{kg}^{-1}\right)=b\left(\mathrm{k}_{\mathrm{p}} /\left(\mathrm{k}_{\mathrm{d}}+\mathrm{k}_{\mathrm{p}}\right)\right)+\mathrm{c}$ where $\mathrm{k}_{\mathrm{p}}=0.05 \mathrm{~h}^{-1}$. Degradability parameters were analyzed by Tukey's multiple comparison (HSD) test $(\mathrm{P}=0.05)$ (Zar, 1999). Statistical analyses were done with the JMP computer program, Version 8 (SAS Institute, 2009).

\section{RESULTS AND DISCUSSION}

Feed chemical composition is shown in Table 1. The CP concentrations in lupin and rapeseed meal remained the same regardless of extruding conditions (Table 1). The reduction in D value and NDF concentration found in lupin and rapeseed meal through extrusion has also been 
Table 1. Mean (SEM, $\mathbf{n}=2$ ) chemical composition of soybean meal (SBM), dehulled lupin (DL), extruded dehulled lupin (EDL), rapeseed meal (RM) and extruded rapeseed meal (ERM).

\begin{tabular}{|c|c|c|c|c|c|}
\hline & SBM & DL & EDL & $\mathrm{RM}$ & ERM \\
\hline $\mathrm{DM}, \mathrm{g} \mathrm{kg}^{-1}$ & $893(0.10)$ & $911(0.15)$ & $879(0.01)$ & $903(0.20)$ & $922(0.15)$ \\
\hline Ash, $\mathrm{g} \mathrm{kg}^{-1} \mathrm{DM}$ & $70.9(0.06)$ & $35.7(0.06)$ & $35.3(0.06)$ & $50.6(0.06)$ & $39.4(1.14)$ \\
\hline $\mathrm{CP}, \mathrm{g} \mathrm{kg}^{-1} \mathrm{DM}$ & $518(1.25)$ & $449(6.70)$ & $453(7.51)$ & $325(0.54)$ & $317(1.01)$ \\
\hline Starch, $\mathrm{g} \mathrm{kg}^{-1} \mathrm{DM}$ & 69.8 (n.a.) & 121.0 (n.a.) & 74.0 (n.a.) & 77.3 (n.a.) & 72.7 (n.a.) \\
\hline $\mathrm{EE}, \mathrm{g} \mathrm{kg}^{-1} \mathrm{DM}$ & $31.8(0.22)$ & $99.1(0.93)$ & $116.4(0.11)$ & $139.7(0.67)$ & $123.4(2.55)$ \\
\hline D value, $\mathrm{g} \mathrm{kg}^{-1} \mathrm{DM}$ & $880.1(3.12)$ & $932.9(0.42)$ & $889.5(2.45)$ & $754.9(1.31)$ & $715.2(4.85)$ \\
\hline ME, Mcal kg-1 DM & $3.14(0.09)$ & $3.31(0.01)$ & $3.17(0.10)$ & $2.74(0.03)$ & $2.61(0.15)$ \\
\hline $\mathrm{NDF}, \mathrm{g} \mathrm{kg}^{-1} \mathrm{DM}$ & $94.7(0.34)$ & $85.6(0.88)$ & $80.2(2.39)$ & $272.4(2.77)$ & $260.6(0.11)$ \\
\hline $\mathrm{ADF}, \mathrm{g} \mathrm{kg}^{-1} \mathrm{DM}$ & $59.2(2.52)$ & $75.5(1.32)$ & $54.3(3.22)$ & $226.0(1.99)$ & $223.9(3.47)$ \\
\hline ADIN, g N/total N & $4.2(0.02)$ & $1.8(0.20)$ & $1.4(0.84)$ & $5.6(0.03)$ & $5.5(0.01)$ \\
\hline
\end{tabular}

Different letters in the same row indicate differences among treatments, unequal N HSD $(\mathrm{P}<0.05)$.

SBM, DL, EDL $130{ }^{\circ} \mathrm{C}-20 \%$ moisture; RM and ERM $120^{\circ} \mathrm{C}-20 \%$ moisture; $n$.a.: not available.

DM: dry matter, CP: crude protein, EE: ether extract, D value: digestible organic matter in DM, ME: metabolizable energy, NDF: neutral detergent fiber, ADF: acid detergent fiber, ADIN: acid detergent insoluble nitrogen.

reported by other authors. This reduction can be due to a partial depolymerization of the polysaccharides of the cell wall, which makes them more soluble in the acid and alkali solutions used during measurements (Solanas et al., 2005). This has also been observed in lupin, in mixtures of peas with extruded rapeseed and extruded corn (Cros et al., 1991; Chapoutot and Sauvant, 1997; Alvarado et al., 2009).

\section{Ruminal degradability}

Table 2 shows the degradation parameters of DM and CP in SBM, DL, EDL, RM, and ERM. Figure 1 shows the degradation curves at $48 \mathrm{~h}$ of in situ fermentation, as well as the equations obtained by the Orskov and MacDonald (1979) model. Of the five evaluated feeds, the lowest concentration of soluble DM and $\mathrm{CP}$ and the highest levels of insoluble DM and $\mathrm{CP}(\mathrm{P}<0.05)$ were observed in SBM. In general, DM degradability was lower than CP degradability, an effect most clearly seen in rapeseed meal. Extrusion in rapeseed meal reduced $\mathrm{CP}$ degradability associated with a reduction of soluble $\mathrm{CP}$ and a slight increase of insoluble $\mathrm{CP}$; conversely, the

Table 2. Degradation parameters of dry matter (DM) and crude protein (CP) for soybean meal (SBM), dehulled lupin (DL), extruded dehulled lupin (EDL), rapeseed meal (RM), and extruded rapeseed meal (ERM) evaluated in situ.

\begin{tabular}{cccccc}
\hline & SBM & DL & EDL & RM & ERM \\
\hline DM: & & & & & \\
$a$ & $296 \mathrm{~d}$ & $362 \mathrm{~b}$ & $346 \mathrm{c}$ & $346 \mathrm{c}$ & $386 \mathrm{a}$ \\
$b$ & $668 \mathrm{a}$ & $639 \mathrm{c}$ & $644 \mathrm{~b}$ & $433 \mathrm{~d}$ & $360 \mathrm{e}$ \\
$\mathrm{k}_{\mathrm{d}}$ & 0.071 & 0.105 & 0.106 & 0.408 & 0.252 \\
$\mathrm{ED} 2$ & $817 \mathrm{c}$ & $899 \mathrm{a}$ & $888 \mathrm{~b}$ & $759 \mathrm{~d}$ & $720 \mathrm{e}$ \\
$\mathrm{ED} 5$ & $688 \mathrm{~d}$ & $795 \mathrm{a}$ & $783 \mathrm{~b}$ & $732 \mathrm{c}$ & $687 \mathrm{~d}$ \\
ED8 & $610 \mathrm{e}$ & $724 \mathrm{a}$ & $713 \mathrm{~b}$ & $708 \mathrm{c}$ & $660 \mathrm{~d}$ \\
\hline CP: & & & & & \\
$a$ & $164 \mathrm{e}$ & $427 \mathrm{~b}$ & $374 \mathrm{~d}$ & $451 \mathrm{a}$ & $390 \mathrm{c}$ \\
$b$ & $858 \mathrm{a}$ & $593 \mathrm{c}$ & $622 \mathrm{~b}$ & $451 \mathrm{e}$ & $457 \mathrm{~d}$ \\
$\mathrm{k}_{\mathrm{d}}$ & $0.051 \mathrm{~b}$ & $0.089 \mathrm{~b}$ & $0.099 \mathrm{~b}$ & $0.608 \mathrm{a}$ & $0.345 \mathrm{~b}$ \\
ED2 & $779 \mathrm{e}$ & $911 \mathrm{a}$ & $892 \mathrm{~b}$ & $888 \mathrm{c}$ & $821 \mathrm{~d}$ \\
ED5 & $596 \mathrm{~d}$ & $807 \mathrm{~b}$ & $788 \mathrm{c}$ & $868 \mathrm{a}$ & $789 \mathrm{c}$ \\
ED8 & $497 \mathrm{e}$ & $740 \mathrm{c}$ & $719 \mathrm{~d}$ & $849 \mathrm{a}$ & $760 \mathrm{~b}$ \\
RUP & $404 \mathrm{a}$ & $193 \mathrm{e}$ & $212 \mathrm{~b}$ & $132 \mathrm{~d}$ & $211 \mathrm{~b}$ \\
\hline
\end{tabular}

$a$ : soluble fraction constant; $b$ : slowly degradable fraction constant; $\mathrm{k}_{\mathrm{d}}: b$ degradation rate ED: effective degradability at three ruminal passage rates $\left(0.02,0.05\right.$, and $\left.0.08 \mathrm{~h}^{-1}\right)$; RUP ruminal undegradable protein $\left(\mathrm{g} \mathrm{kg}^{-1}\right)=\mathrm{b}\left(\mathrm{k}_{\mathrm{p}} /\left(\mathrm{k}_{\mathrm{d}}+\mathrm{k}_{\mathrm{p}}\right)\right)+\mathrm{c}$ where $\mathrm{k}_{\mathrm{p}}: 0.05 \mathrm{~h}^{-1}$

Different letters in each row correspond to significant differences according to Tukey's multiple comparison HSD test $(\mathrm{P}<0.05)$.

SBM, DL, and EDL $130{ }^{\circ} \mathrm{C}-20 \%$ moisture; RM and ERM $120{ }^{\circ} \mathrm{C}-20 \%$ moisture.

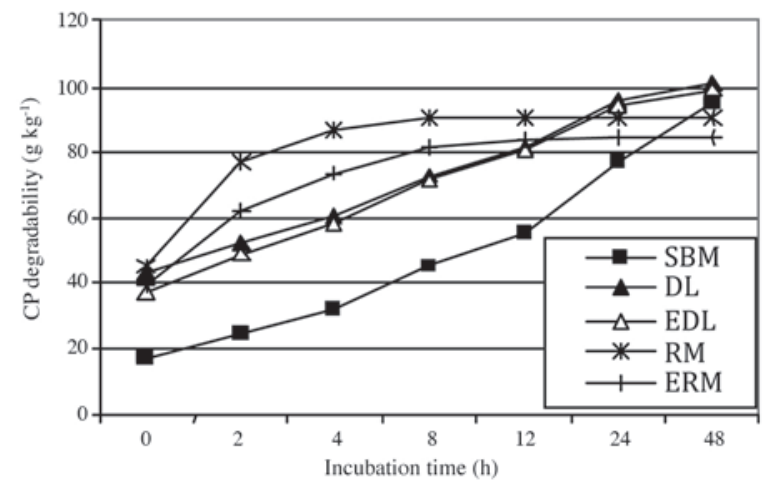

SBM: $\left(\mathrm{p}=164+858(1-\mathrm{e})^{-0.051 \mathrm{t}} ; \mathrm{R}^{2}=0.99 ; \mathrm{p}=0.0001\right) ; \mathrm{DL}:\left(\mathrm{p}=427+593(1-\mathrm{e})^{-0.089 t} ; \mathrm{R}^{2}=\right.$ 0.99; $\mathrm{p}=0.0002)$; EDL: $\left(130{ }^{\circ} \mathrm{C}-20 \%\right.$ moisture $)\left(\mathrm{p}=374+622(1-\mathrm{e})^{-0.099 t} ; \mathrm{R}^{2}=0.97 ; \mathrm{p}=\right.$ $0.001)$; RM: $\left(\mathrm{p}=451+451(1-\mathrm{e})^{-0.608 t} ; \mathrm{R}^{2}=0.98 ; \mathrm{p}=0.0003\right)$; ERM: $\left(120{ }^{\circ} \mathrm{C}-20 \%\right.$ moisture $\left(\mathrm{p}=390+457(1-\mathrm{e})^{-0.345 t} ; \mathrm{R}^{2}=0.92 ; \mathrm{p}=0.006\right)$.

Figure 1. Predicted values of in situ crude protein (CP) degradation for soybean meal (SBM), dehulled lupin (DL), extruded dehulled lupin (EDL), rapeseed meal (RM), and extruded rapeseed meal (ERM).

opposite was observed for DM $(\mathrm{P}<0.05)$. Extrusion in lupin did not clearly modify DM and CP degradability; however, a reduction of soluble $\mathrm{CP}$ and DM, as well as an increase of insoluble $\mathrm{CP}$ and $\mathrm{DM}$ were observed $(\mathrm{P}<$ $0.05)$. Comparatively, rapeseed total degradability was lower especially for the DM fraction, and this effect could be attributed to higher fiber (ADF) and ADIN concentrations. Protein meals of plant origin typically show high values of ruminal $\mathrm{CP}$ degradability that can fluctuate around $770 \mathrm{~g} \mathrm{~kg}^{-1} \mathrm{ED}$ in by-products such as rapeseed meal (Tuncer and Sacakli, 2003), be higher in leguminous grains, e.g., $951 \mathrm{~g} \mathrm{~kg}^{-1} \mathrm{ED}$ degradability in lupin (Cros et al., 1991), and 916, 981, and $905 \mathrm{~g} \mathrm{~kg}^{-1} \mathrm{ED}$ degradability in lupin, peas, and soybeans, respectively (Solanas et al., 2005). The most noticeable effect of extrusion was a reduction in soluble CP (" $a$ ") coupled with an increase of insoluble CP (" $b$ ") in both DL and RM (Table 2). These changes in DL were not reflected in total degradability; however, RM extrusion reduced total degradability $(6.5 \%)$. Different authors have observed increases of insoluble CP for lupin meal as a result of extrusion, ranging from 57.14 to $74.51 \%$ in Cros et al., 
1991, and 49.56 and $52.21 \%$ for Aufrère et al., 2001 and Rémond et al., 2003, respectively. However, the increase of insoluble protein in lupin found in this study was much lower (4.8\%), which could be due to the use of dehulled lupin. Lampart-Szczapa et al. (2006), when comparing normal and dehulled lupin seeds, found a lower water absorption capacity in dehulled lupin, an effect which should negatively influence the Maillard reaction. Therefore, the combination of temperature and moisture applied to EDL (130 ${ }^{\circ} \mathrm{C}-20 \%$ moisture) was apparently not sufficient to generate structural changes in the protein due to the Maillard reaction along with the lower water absorption capacity of the dehulled seed.

Extrusion in RM produced a small increase of insoluble protein $(1.3 \%)$, and a higher reduction of soluble CP (13.6\%). The DM degradability showed a different pattern with decreasing soluble DM and increasing insoluble DM, although CP and DM degradability decreased after extrusion in accordance with the results of Vanhatalo et al. (1995); Wulf and Südekum (2005); and Sadeghi and Shawrang (2006).

Several authors have sought to understand the effect of heat treatment on degradation dynamics by studying the protein structure of evaluated feeds and proteins present in the residues after fermentation. White lupin, soybean meal, and rapeseed meal contain two main types of proteins: albumins (soluble in water) and globulins (soluble in saline solutions) (Duranti et al., 1981; Aufrère et al., 1994; van Barneveld, 1999; Sadeghi and Shawrang, 2006). Extrusion can modify the protein structure by destroying many covalent and non-covalent bonds that would stabilize the secondary structure while new intermolecular bonds can form to create sub-units (Lampart-Szczapa et al., 2006).

In lupin seed, $\alpha$-conglutin with disulphide bonds represents 35 to $37 \%$ of globulin concentration (Duranti et al., 1981; 2008). The $\beta$-conglutin, the most abundant protein in lupin (45\% of total globulins) has no disulphide bonds (Duranti et al., 1981; 2008). Aufrère et al. (2001) analyzed the residues of ruminal incubation of extruded and unextruded lupin by electrophoresis and found no $\beta$-conglutin. However, $\alpha$-conglutin was detected in unextruded lupin up to $8 \mathrm{~h}$ of fermentation and in extruded lupin up to $16 \mathrm{~h}$; these authors proposed that the absence of disulphide bonds in $\beta$-conglutin could explain its rapid disappearance from the residues. Furthermore, the main proteins in RSM are napin ( $2 \mathrm{~S}$ albumin) and cruciferin (12S globulin) (Sadeghi and Shawrang, 2006) where napin protein is less heat resistant than cruciferin (Folawiyo and Apenten, 1997). In this study, the CP soluble fraction in ERM was reduced as a result of extrusion. Applying heat $\left(90{ }^{\circ} \mathrm{C}\right)$ to napin produces an irreversible but relatively moderate decrease in surface hydrophobicity (Folawiyo and Apenten, 1997). According to Lampart-Szczapa et al. (2006), hydrophobicity reactions are important in maintaining intramolecular structural stability. These authors also indicate that due to the diverse composition of proteins in RSM, it is difficult to select a temperature at which all the protein sub-units are denaturalized or added at the same time. This may also be true for other protein feeds subjected to thermal processing. Sadeghi and Shawrang (2006) reported that the electrophoresis pattern of untreated rapeseed meal showed that the napin subunit (albumin) disappeared at zero incubation time; the cruciferin sub-unit (globulin) degraded slowly and was still not completely degraded after $48 \mathrm{~h}$ fermentation, thus representing a large part of the protein remaining after 12 $\mathrm{h}$ incubation. Consistent with the abovementioned, Figure 1 shows that the CP fraction in RM reached maximum degradation after 8 to $12 \mathrm{~h}$ of incubation.

The RM protein degradation rate (" $k_{d}$ ") was greater for $\mathrm{CP}$ than for DM, whereas the opposite was found for lupin seed and SBM. Extrusion reduced CP degradation rate in $\mathrm{RM}$ but not in lupin $(\mathrm{P}<0.05)$. Higher $\mathrm{CP}$ degradation rates observed with RM as compared to DL and SBM could be related to the lower processing temperature (less than $60^{\circ} \mathrm{C}$ ) used in SBM in the oil extraction process (cold extraction of oil under pressure expeller, screw pressing), and to a residual oil concentration about five times greater than solvent-extracted RM. Therefore, the protein fraction is expected to have low heat damage.

The " $k_{d}$ " value of CP in DL $\left(0.089 \mathrm{~h}^{-1}\right)$ was lower than the rates of $0.748 \mathrm{~h}^{-1}, 0.200 \mathrm{~h}^{-1}$, and $0.534 \mathrm{~h}^{-1}$ obtained by Aufrère et al.(2001), Rémond et al.(2003), and Mogensen et al. (2008), respectively. The lower " $\mathrm{k}_{\mathrm{d}}$ " value of lupin in this study can be due to using dehulled lupin since the cited studies used whole ground lupin grain. The " $k_{d}$ " value for $\operatorname{EDL}\left(0.099 \mathrm{~h}^{-1}\right)$ is similar to the $0.089 \mathrm{~h}^{-1}$ and 0.06 $\mathrm{h}^{-1}$ values obtained by Aufrère et al. (2001) and Rémond et al. (2003), respectively, who worked with extruded lupin. It also agrees with the $0.096 \mathrm{~h}^{-1}$ value reported by Mogensen et al. (2008) with toasted lupin. A " $k_{d}$ " value of $0.608 \mathrm{~h}^{-1}$ for $\mathrm{CP}$ was obtained in the unprocessed rapeseed meal treatment $(\mathrm{RM})$, which is higher than the 0.180 and $0.157 \mathrm{~h}^{-1}$ values reported by Vanhatalo et al. (1995), $0.068 \mathrm{~h}^{-1}$ by Wulf and Südekum (2005), and $0.064 \mathrm{~h}^{-1}$ by Sadeghi and Shawrang (2006). However, it was lower than the $0.93 \mathrm{~h}^{-1}$ value obtained by Tuncer and Sacakli (2003). The different degradation rates obtained in these reports may be explained in part by the diversity in the chemical composition of these by-products. In Tuncer and Sacakli (2003), CP and EE concentrations were 277 and $210 \mathrm{~g} \mathrm{~kg}^{-1}$, respectively, while values in this study were 325 and $140 \mathrm{~g} \mathrm{~kg}^{-1}$ for $\mathrm{CP}$ and EE, respectively. In both cases, oil was extracted under pressure (screw-pressing), which resulted in a higher residual oil concentration in the by-product. The lower CP concentration and the higher oil concentration, as compared with other studies (e.g., Vanhatalo et al., 1995; Kokkonen et al., 2000; Harstad and Prestlokken, 2001), can increase the degradation rate in these feeds. Moreover, the " $k_{d}$ " value in ERM in this study was reduced by extrusion $\left(0.345 \mathrm{~h}^{-1}\right)$, fact also 
observed by Tuncer and Sacakli (2003) in treatments with 5,10 , and $20 \mathrm{~g}$ of xylose (" $\mathrm{k}_{\mathrm{d}}$ " values between 1.01 and $\left.0.38 \mathrm{~h}^{-1}\right)$. However, the degradation rate was higher than the 0.105 and $0.118 \mathrm{~h}^{-1}$ values (with moisture-heat-treated rapeseed meal) obtained by Vanhatalo et al. (1995), 0.033 $\mathrm{h}^{-1}$ (rapeseed meal expeller treated with xylose) by Wulf and Südekum (2005), and $0.038 \mathrm{~h}^{-1}$ (microwave irradiated rapeseed) by Sadeghi and Shawrang (2006).

A lower ED of DM (with $\mathrm{k}_{\mathrm{d}} 0.05 \mathrm{~h}^{-1}$ ) was found in SBM and ERM, while DL and EDL exhibited higher levels of ED (Table 2) $(\mathrm{P}<0.05)$. Extrusion slightly reduced ED $(1.46 \%)$ of EDL as compared with DL. The ED $(0.05$ $\mathrm{h}^{-1}$ ) of CP fluctuated between $596 \mathrm{~g} \mathrm{~kg}^{-1}$ in SBM and 869 $\mathrm{g} \mathrm{kg}^{-1}$ in RM. The DL showed a lower ED (807 $\left.\mathrm{g} \mathrm{kg}^{-1}\right)$ when compared to values by Cros et al. (1991), Aufrère et al. (2001), Rémond et al. (2003) (951, 954, and 961 $\mathrm{g} \mathrm{kg}^{-1}$ respectively; $\left.\mathrm{k}_{\mathrm{d}} 0.06 \mathrm{~h}^{-1}\right)$, as well as Solanas et al. (2005) (916 $\left.\mathrm{g} \mathrm{kg}^{-1}, \mathrm{k}_{\mathrm{d}} 0.05 \mathrm{~h}^{-1}\right)$. However, extruded lupin ED exhibited a greater similarity with values reported in the literature (Cros et al., 1991; Aufrère et al., 2001; Rémond et al., 2003; Solanas et al., 2005) (836, 682, 746, and $738 \mathrm{~g} \mathrm{~kg}^{-1}$, respectively). This would indicate that extrusion produced a similar effect in lupin, whether it was previously treated or not. In the case of ERM, ED was reduced by $6.14 \%$ when compared to RM. The protein ED in lupin was lower in EDL than in DL by $2.35 \%$ (Figure 1). However, it is higher than the values found in the literature in RM (Prestlokken, 1999; Wulf and Südekum, 2005; Sadeghi and Shawrang, 2006; Lund et al., 2008). Extrusion reduced effective RM degradability by $9.1 \%$ (Figure 1); this result was similar to the ED value obtained by Tuncer and Sacakli (2003) in a treatment with $5 \mathrm{~g}$ of xylose. This could be due to the fact that in feeds with certain restrictions (a lower concentration of lysine and reducing sugars, such as in rapeseed meal) the effect of processing can be strengthened by increasing the moisture applied and/or adding a source of reducing sugar such as xylose (Hoskin and Dimick, 1995; Solanas et al., 2005). As a consequence of extrusion, RUP increased in EDL by $8.96 \%$ and $37.35 \%$ in ERM, which would allow increasing metabolizable protein availability and, consequently, AA in the intestine.

The depressing effect of the rate of passage on degradability was in SBM, intermediate in DL and the lowest in RM (Figure 2). Protein degradability at the highest rate of passage $\left(0.08 \mathrm{~h}^{-1}\right)$ decreased $51.4,27.5$, 27.8, 5.9, and $10.3 \%$ for SBM, DL, EDL, RM, and REM, respectively, as regards " $a$ " $+" b$ " and showing that DE was more markedly reduced with a higher " $b$ ". At a 0.05 $\mathrm{h}^{-1}$ passage rate, the decrease in lupin degradability was $20.9 \%$, a value similar to the reduction of $21 \%$ reported by Rémond et al. (2003). In general, the depressing effect of the passage rate on degradability should be lower in feeds rich in " $a$ " or slower " $b$ " degradability. Feeds most affected by the passage rate are those rich in insoluble fraction and medium to low degradability.

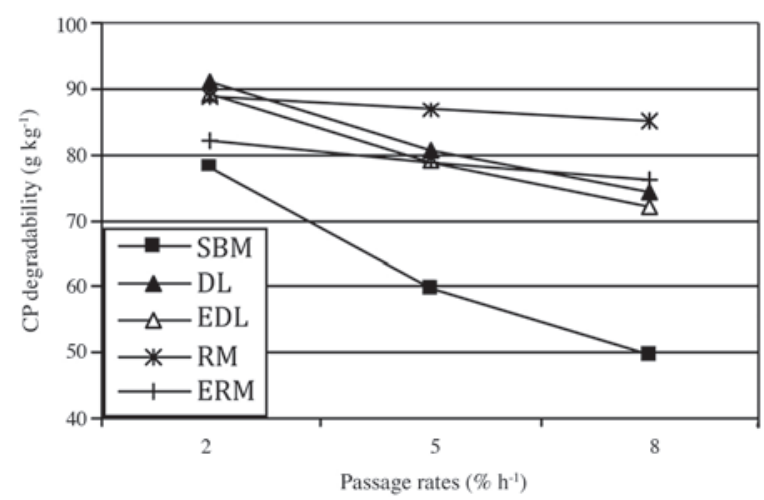

SBM: soybean meal; DL: dehulled lupin; EDL: extruded dehulled lupin $\left(130{ }^{\circ} \mathrm{C}-20 \%\right.$ moisture); RM: rapeseed meal; ERM: extruded rapeseed meal $\left(120^{\circ} \mathrm{C}-20 \%\right.$ moisture).

Figure 2. Effective degradability of crude protein (CP) degraded with three passage rates.

Although statistically significant, the increase of insoluble protein in lupin was small and reduced degradability only slightly, but the effect of the passage rate was similar independently of extrusion. A relationship was found between insoluble protein (\% total protein) $(\mathrm{X})$ and the ED decrease of protein $(\mathrm{Y})\left(\mathrm{Y}=-79.9+1.72 \mathrm{X}, \mathrm{R}^{2}=\right.$ 0.95), showing that ED decreased by 1.72 units for each unit increase of insoluble protein.

The reduction of ED in EDL and ERM due to extrusion and the resulting increase in RUP is consistent with the results in the literature where it is reported that heat processing of lupin and rapeseed meal increases the fraction of undegraded protein in the rumen without reducing $\mathrm{CP}$ intestinal digestibility (Vanhatalo et al., 1995).

\section{CONCLUSIONS}

Moist extrusion allows reducing ruminal degradability of lupin and rapeseed meal, thus increasing intestinal availability of undegraded rumen protein. The effect of extrusion on effective degradability was greater in rapeseed meal than in dehulled lupin. The temperature applied to dehulled lupin would be insufficient to obtain a greater response and further investigation is needed in this field. In rapeseed meal, extrusion reduced both the degradation of dry matter and crude protein; it also increased undegraded protein in the rumen, thus showing the potential to increase the supply of metabolizable protein.

\section{ACKNOWLEDGEMENTS}

This research was made possible thanks to financing by Project DI07-0053 of the Research Directorate of the Universidad de La Frontera (Temuco, Chile). Claudia Barchiesi received a grant from the MECESUP, Higher Education Program of the Chilean Ministry of Education. 
This paper is part of the doctoral thesis in the Faculty of Agrarian Sciences of the Universidad Austral de Chile.

Degradabilidad ruminal de la materia seca y de la proteína cruda de lupino descascarado y torta de raps extruidos. El flujo de proteína no degradable en el rumen (RUP) hacia el intestino delgado puede ser incrementado si se reduce la degradación ruminal de la proteína dietaria. El objetivo de este trabajo fue evaluar el efecto de la extrusión sobre la degradabilidad ruminal de la materia seca (DM) y proteína cruda (CP) de lupino (Lupinus albus L.) descascarado (DL) y torta de raps (Brassica napus L.) (RM). Se utilizó afrecho de soya (Glicine max L.) sin extruir (SBM) como control. El DL fue extruido a $130{ }^{\circ} \mathrm{C}$ con $20 \%$ de humedad y la RM fue extruida a 120 ${ }^{\circ} \mathrm{C}$ con $20 \%$ de humedad. La degradabilidad ruminal se evaluó in situ incubando las muestras de alimentos a 2, $4,8,12,24$ y 48 h de fermentación en tres vacas lecheras con fístula ruminal. Los valores de la fracción soluble de la CP (" $a$ ") en SBM, en DL, lupino descascarado extruido (EDL), RM y torta de raps extruida (ERM) fue menor en los extruidos $(\mathrm{P}<0.05)$. La fracción lentamente degradable (" $b$ ") de SBM, DL, EDL, RM y de ERM fue 858; 593; 622 y 451 y $457 \mathrm{~g} \mathrm{~kg}^{-1}$, respectivamente, y se incrementó por extrusión $(\mathrm{P}<0.05)$. La extrusión redujo la degradabilidad efectiva ( $\mathrm{Dg}$ ) de la $\mathrm{CP}$ en lupino desde 807 a $788 \mathrm{~g} \mathrm{~kg}^{-1} ; \mathrm{kp}=0.05 \mathrm{~h}^{-1}$, mientras que en ERM la Dg se redujo desde 86.8 hasta $78.9 \%$; $\mathrm{kp}=0.05 \mathrm{~h}^{-1}$. Ello incrementó la proteína no degradable en el rumen (RUP) en $8.95 \%$ en EDL $(\mathrm{P}<0.05)$; y en ERM el incremento fue de $37.35 \%(\mathrm{P}<0.05)$. Se puede concluir que la extrusión en presencia de humedad redujo la degrabilidad de la CP, especialmente en el caso de ERM.

Palabras clave: extrusión, suplementos proteicos, degradación proteica, afrecho de soya, vacas lecheras.

\section{LITERATURE CITED}

AACC. 2000. Approved methods of the AACC. Method 76.13. $10^{\text {th }}$ ed. American Association of Cereal Chemistry (AACC), St. Paul, Minnesota, USA.

Agricultural Research Council. 1984. The nutrient requirements of ruminant livestock. Suppl. $\mathrm{N}^{\circ} 1$. Commonwealth Agricultural Bureaux, Farnham Royal, UK.

Alvarado, Ch., R. Anrique, and S. Navarrete. 2009. Effect of including extruded, rolled or ground corn in dairy cow diets based on direct cut grass silage. Chilean Journal of Agriculture Research 69:356-365.

AOAC. 1995. Official methods of analysis. $15^{\text {th }}$ ed. Association of Official Analytical Chemists (AOAC), Washington, DC., USA.

Aufrère, J., D. Graviou, J. Melcion, and C. Demarquilly. 2001. Degradation in the rumen of lupin (Lupinus albus L.) and pea (Pisum sativum L.) seed proteins: Effects of heat treatment. Animal Feed Science and Technology 92:215-236.

Aufrère, J., D. Graviou, and B. Michalet-Doreau. 1994. Degradation in the rumen of proteins of 2 legumes: soybean meal and field pea. Reproduction Nutrition and Development 34:483-490.

Borucki-Castro, S.I., L.E. Phillip, H. Lapierre, P.W. Jardon, and R. Berthiaume. 2007. Ruminal degradability and intestinal digestibility of protein and amino acids in treated soybean meal products. Journal of Dairy Science 90:810-822.
Cros, P., C. Benchaar, C. Bayourthe, M. Vernay, and R. Moncoulon. 1991. In situ evaluation of the ruminal and intestinal degradability of extruded whole lupin seeds nitrogen. Reproduction Nutrition and Development 31:575-583.

Chapoutot, P., and D. Sauvant. 1997: Nutritive value of raw and extruded pea-rapeseeds blends for ruminants. Animal Feed Science and Technology 65:59-77.

Duranti, M., A. Consonni, Ch. Magni, F. Sessa, and A. Scarafoni. 2008. The major proteins of lupin seed: characterisation and molecular properties for use as functional and nutraceutical ingredients. Trends in Food Science \& Technology 19:624-633.

Duranti, M., P. Restani, M. Poniatowska, and F. Cerletti. 1981. The seed globulins of Lupinus albus. Phytochemistry 56:529-533.

Folawiyo, Y.L., and R.K. Apenten. 1997. The effect of heat- and acid- treatment on the structure of rapeseed albumin (napin). Food Chemistry 58:237-243.

Goering, H., and P. Van Soest. 1972. Forage fiber analyses (apparatus, reagents, procedures, and some applications). Agriculture Handbook $N^{\circ} 379$. Agricultural Research Service (ARS), USDA, Washington DC., USA.

González, J., J. Faría-Mármol, C.A. Rodríguez, M. Ouarti, M.R. Alvirand, and C. Centeno. 2006. Protein value for ruminants of a sample of whole cottonseed. Animal Science 82:75-81.

Guada, J. 1993. Efectos del procesado sobre la degradabilidad ruminal de la proteína y almidón. IX curso de especialización FEDNA (On Line). Available at www.etsia.upm.es/fedna/ capitulos/93CAP_2.pdf.

Harstad, O., and E. Prestlokken. 2001. Rumen degradability and intestinal indigestibility of individual amino acids in corn gluten meal, canola meal and fish meal determined in situ. Animal Feed Science and Technology 94:127-135.

Hoskin, J., and P. Dimick. 1995. Non enzymatic browning of foods. p. 65-79. In Beckett, S. (ed.) Physicochemical aspects of food processing. Blackie Academic \& Professional, Glasgow. UK.

Kokkonen, T., M. Tuori, L. Leivonen, and L. Syrjälä-Qvist. 2000. Effect of silage dry matter content and rapeseed meal supplementation on dairy cows. 1. Milk production and feed utilisation. Animal Feed Science and Technology 84:213-228.

Lampart-Szczapa, E., P. Konieczny, M. Nogala-Kałucka, S. Walczak, I. Kossowska, and M. Malinowska. 2006. Some functional properties of lupin proteins modified by lactic fermentation and extrusion. Food Chemistry 96:290-296.

Lund, P., M.R. Weisbjerg, and T. Hvelplund. 2008. Profile of digested feed amino acids from untreated and expander treated feeds estimated using in situ methods in dairy cows. Livestock Science 114:62-74

Mogensen, L., P. Lund, T. Kristensen, and M. Weisbjerg. 2008. Effects of toasting blue lupins, soybeans or barley as supplement for high-yielding, organic dairy cows fed grass-clover silage $a d$ libitum. Livestock Science 115:249-257.

Moshtaghi Nia, S.A., and J.R. Ingalls. 1995. Influence of moist heat treatment on ruminal and intestinal disappearance of amino acids from rapeseed meal. Journal of Dairy Science 78:1552-1560.

NRC. 2001. Nutrient requirements of dairy cattle. $17^{\text {th }}$ revised edition. National Research Council National Academy Press, Washington, DC., USA.

Orskov, E.R., and I. McDonald. 1979. The estimation of protein degradability in the rumen from incubation measurements weighted according to rate of passage. Journal of Agriculture Science 92:499-503.

Prestlokken, E. 1999. In situ ruminal degradation and intestinal digestibility of dry matter and protein in expanded feedstuffs. Animal Feed Science and Technology 77:1-23.

Rémond, D., M. Le Guen, and C. Poncet. 2003. Degradation in the rumen and nutritional value of lupin (Lupinus albus L.) seed proteins effect of extrusion. Animal Feed Science and Technology 105:55-70

Sadeghi, A., and P. Shawrang. 2006. Effects of microwave irradiation on ruminal degradability and in vitro digestibility of canola meal. Animal Feed Science and Technology 127:45-54. 
Sarrazin, P.,A. Mustafa, Y.Chouinard, G. Raghavan, and S. Sotocinal. 2003. Effects of roasting on ruminal nutrient degradability of sunflower seed. Journal of the Science of Food and Agriculture 83:1219-1224.

SAS Institute. 2009. JMP 8 Design of Experiments. SAS Institute, Cary, North Carolina, USA

Schwab, C.G., P. Huhtanen, C.W. Huht, and T. Hvelplund. 2005 Nitrogen requirements of cattle. p. 13-70. In Pfeffer, E., and A.N Hristov (eds.) Nitrogen and phosphorus nutrition of cattle. CAB International, Wallingford, UK.

Solanas, E., C. Castrillo, J. Balcells, and J.A. Guada. 2005. In situ ruminal degradability and intestinal digestion of raw and extruded legume seeds and soya bean meal protein. Journal of Animal Physiology and Animal Nutrition 89:166-171.

Svihus, B., A. Uhlen, and O. Harstad. 2005. Effect of starch granule structure, associated components and processing on nutritive value of cereal starch: A review. Animal Feed Science and Technology 122:303-320.

Tuncer, S., and P. Sacakli. 2003. Rumen degradability characteristics of xylose treated canola and soybean meals. Short communication. Animal Feed Science and Technology 107:211-218. van Barneveld, R. 1999. Understanding the nutritional chemistry of lupin (Lupinus spp.) seed to improve livestock production efficiency. Nutrition Research and Review 12:203-230.

Van Soest, P.J., J. Robertson, and B. Lewis. 1991. Methods for dietary fiber, neutral detergent fiber and non starch polysaccharides in relation to animal nutrition. Journal of Dairy Science 74:35833597.

Vanhatalo, A., I. Aronen, and T. Varvikko. 1995. Intestinal nitrogen digestibility of heat-moisture treated rapeseed meals as assessed by the mobile bag method in cows. Animal Feed Science and Technology 55:139-152.

Wright, C., M. von Keyserlingk, M. Swift, L. Fisher, J. Shelford, and N. Dinn. 2005. Heat- and lignosulfonate-treated canola meal as a source of ruminal undegradable protein for lactating dairy cows Journal of Dairy Science 88:238-243.

Wulf, M., and K.H. Südekum. 2005. Effects of chemically treated soybeans and expeller rapeseed meal on in vivo and in situ crude fat and crude protein disappearance from the rumen. Animal Feed Science and Technology 118:215-227.

Zar, J.H. 1999. Biostatistical analysis. $14^{\text {th }}$ ed. Prentice-Hall, Upper Saddle River, New Jersey, USA. 